\title{
Structural Engineering Heroes and Their Inspirational Journey
}

\author{
Ignacio Paya-Zaforteza Prof. Dr \& Maria E. M. Garlock Prof. Dr
}

To cite this article: Ignacio Paya-Zaforteza Prof. Dr \& Maria E. M. Garlock Prof. Dr (2021):

Structural Engineering Heroes and Their Inspirational Journey, Structural Engineering International, DOI: $10.1080 / 10168664.2021 .1919038$

To link to this article: https://doi.org/10.1080/10168664.2021.1919038

曲 Published online: 07 Jul 2021.

Submit your article to this journal $₫$

Џll Article views: 6

Q View related articles ๘

View Crossmark data 


\title{
Structural Engineering Heroes and Their Inspirational Journey
}

\author{
Ignacio Paya-Zaforteza (D), Prof. Dr, Universitat Politècnica de València - ICITECH, València, Spain; Maria E. M. Garlock (D), Prof. Dr, \\ Princeton University, Princeton, USA. Contact: igpaza@cst.upv.es. \\ DOI: $10.1080 / 10168664.2021 .1919038$
}

\begin{abstract}
In the nineteenth century, civil and structural engineers received much public acclaim for their built works (e.g. Brooklyn Bridge, Eiffel Tower). One hundred years later, the engineer was perceived by many as "out" or as not requiring much skill. This paper examines how this erroneous perception of structural engineering can change by presenting structural engineers as heroes. Using parallels to the monomythical hero, and examples of engineers, the authors present the journey and characteristics of the structural engineering hero. The journey, which has many paths, begins with the engineer leaving the comfortable "Ordinary World" of design into a "Special World", where new forms, new materials, and/or scale for projects is needed. For underrepresented groups of people such as women and minorities, the heroic journey could be simply becoming an engineer and developing a career in conditions of equality and equity. As structural engineering heroes enter the Special World, they may face trials of nature and criticism, and face constraints of economy, time and knowledge. In the final Act of the journey, they return to the Ordinary World wiser, disseminating their knowledge and inspiring others. The authors define the characteristics of structural engineering heroes by four "P"s: they are prepared, they are planners, they have (super) powers and they are persona grata. The education of the structural engineer should train and inspire future engineers using the lessons learned from the heroes and their diversity. By doing so, what seems exceptional today can become common in the future.
\end{abstract}

KEYWORDS: Engineering hero; engineering education; diversity; Joseph Campbell; monomyth; philosophy of structures; conceptual design

\section{Introduction}

The Royal Charter of the Institution of Civil Engineers (ICE) signed by George IV in 1828 includes the definition of civil engineering proposed by Thomas Tredgold in 1828, which considered the profession as "the art of directing the great sources of power in nature for the use and convenience of man". During the nineteenth century the development of transportation networks and the construction of buildings for these networks (e.g. train stations) and exhibition halls resulted in the public acclaim of the civil and structural engineer. Works such as the Menai Bridge (1826), the Maria Pia viaduct (1877), the Brooklyn Bridge (1883), the Galerie des Machines exhibition hall (1889), the Eiffel Tower (1889), and the Firth of Fourth Bridge (1890) made civil and structural engineering a profession highly esteemed by society.

At the end of the twentieth century the view of the civil engineer was completely different. For example, Lorenz ${ }^{1}$ summarized the findings of a survey conducted in Switzerland in 1989 among civil engineering students and young professionals. Half of the graduates who replied to the survey considered their profession as "out", $60 \%$ considered themselves as calculating menials, $87 \%$ thought themselves to be seen as "destroyers of nature". According to Lorenz, ${ }^{1}$ the profession had lost in a few decades the prestige amassed over two centuengineer's profession into the meaninglessness of a technician's job" and construction history was a key resource to solve the civil engineering crisis. Years later, the situation had not experienced any significant improvement. Arciszewski and Harrisson $^{2}$ considered that if the success of a profession was measured by its prestige, social position, salaries and ability to attract the best and brightest students, civil engineering was not in a good position. These authors proposed a new civil engineering education paradigm that would get engineers ries and faced the "dissolution of the ready for practice but also for becoming leaders able to implement and develop novel solutions and be opportunity seekers. For Arciszewski and Harrisson, ${ }^{2}$ creativity was one of the most important keys to the survival of the profession. Their proposal included a series of political, technical and methodological goals, one of them being "Civil engineers [should be] perceived again by society as leaders and heroes of our civilization". The current lack of attractiveness of civil engineering is also visible within cultural manifestations of our time as shown for example in a recent successful movie, Frozen 2, where a major engineering work, a dam, had to be destroyed to break a spell and restore peace. This general situation should change, and in fact many activities and projects prove that civil and structural engineering can be appealing to all kinds of people (the general public, high school students, engineering students,...). For example, Garlock has created two massive open on-line courses (MOOCs) devoted to the art of structural engineering. "The Art of Structural Engineering: Bridges"3 was launched in 2016 and relaunched in 2019, and it enrolled over 24,000 students representing 184 counties. "The Art of Structural Engineering: Vaults" 4 was launched in 2018 and it enrolled over 13,000 students representing 169 counties. These courses have been a great success and generally praised by their students with comments such as "your MOOCs ... changed my professional life and encouraged me to work harder in my studies"5 and "Thank you for helping me see that there is a path for me to experience the beautiful intersection between art and engineering. Please keep doing what you are doing because it really has changed my outlook on academics". 6

Important efforts have also been made by professional associations such as the International Association for Bridge and Structural Engineering 
(IABSE) or the ICE. IABSE organized a conference in Bath in 2017 with the theme "Creativity and Collaboration. Instilling imagination and innovation in structural design"7 aimed at promoting creativity in design and the collaborative processes that generate innovation and design excellence in the built environment. The proceedings of this conference contain many examples of outreach activities and innovative approaches to teach and learn structural engineering (see e.g. Refs. [8,9]). ICE, for its part, and on the occasion of its 200th anniversary, created the exhibition "Invisible superheroes" using a comic book style to explain how civil engineering transforms the world together with stories of the heroes behind some of the world's most astounding projects. The exhibition can now be visited virtually. ${ }^{10}$

Therefore, there is agreement on the need and advantages of looking again at civil engineers as heroes of our society. This paper updates this classic role of the engineer using a new perspective inspired by the work of Joseph Campbell (1904-1987). Campbell, a renowned mythologist and university professor, studied myths and their heroes from all around the world and found patterns common to all of them. This paper establishes a parallelism between mythical heroes and structural engineers. In this context of the hero, the paper answers several questions such as: What is the journey of the structural engineering hero? Do all (or many) of the great structural engineers share some common characteristics? What are these characteristics? How can we educate our future engineers so that what today is exceptional becomes common in future? Answers to these questions are given based on the life and works of great engineers of the past and the present, and high-value clues are provided for educating a diverse group of future engineers and for increasing the recognition of the profession by society.

\section{Joseph Campbell and the Monomyth}

According to Campbell's monomyth theory, myths from all around the world have a common structure no matter when and where they were created. Campbell's ideas are presented in his most influential book,
"The hero with a thousand faces", where "the hero's journey" is summarized as follows:

A hero ventures forth from the world of common day into a region of supernatural wonder: fabulous forces are there encountered and a decisive victory is won: the hero comes back from this mysterious adventure with the power to bestow boons on his fellow man.

The hero's journey consists of three basic Acts containing a total of 17 stages, although not all the myths contain them all. In the first Act, the departure, the hero receives a call to adventure that pushes him/her to move out from his/her comfort zone (the "Ordinary World"). The hero might be reluctant to move out from the Ordinary World but will have a first encounter with a protective figure that provides amulets and advice the hero requires to pursue the adventure. The hero moves then into the unknown or "Special World". This fact marks the beginning of the second Act, the initiation, where the hero faces trials and temptations, and must accomplish some tasks, alone or with the help of someone. The hero might fail in some of the trials but finally he/she will overcome them and gain recognition in the form of a reward. In the third Act, the return, the hero comes back to the Ordinary World with his/her reward. The hero has been transformed by the process and can use the wisdom gained in both the special and the Ordinary
World for the benefit of his/her fellows. Campbell's ideas have had a tremendous influence in important cultural manifestations of our time such as the Star Wars saga ${ }^{12}$ and have been used, for example, to understand videogames narratives, ${ }^{13}$ to study how students transfer into engineering from other majors ${ }^{14}$ or to analyse three chefs' biographies, ${ }^{15}$ the latter work containing also a summary of the ideas presented by some of Campbell's critics. To the authors' knowledge, however, this framework has not been applied to explain the work of the structural engineer.

\section{The Structural Engineer's Journey}

The structural engineer's journey has many similarities with the hero's journey. This is explained in the following sections using the monomyth structure of three Acts and summarized in Fig. 1. A hero's journey within the three Acts has many possible paths, just as structural engineering projects have multiple potential solutions, not all of them having the same quality. The engineering heroes are recognized for providing outstanding quality designs, where the concept "outstanding quality" has multiple interpretations. For Billington, ${ }^{16}$ engineering works achieve excellence when they maximize three ideals: efficiency, economy and elegance. For the Institution of Structural Engineers, and according to its structural awards judging criteria, excellence involves

\section{ORDINARY WORLD}

\section{ACT 1: DEPARTURE}

- Hero gets called to adventure, moves out of comfort zone.

- Engineer gets called to new project with new forms, materials, and/or scale.

\section{ACT 3: RETURN}

- Hero transformed by journey and gains wisdom for benefit of others.

- Engineer emerges from journey wiser and disseminates knowledge.

\section{SPECIAL WORLD}

ACT 2: INITIATION

- Hero faces trials \& temptations, and meets enemies \& allies in the quest.

- Engineer faces challenges of nature (wind, EQ, etc.) and criticism, and constraints of economy, time, knowledge. Sometimes aided by allies such as other colleagues or resources of knowledge.

Fig. 1: The monomyth structure of the hero's journey in three Acts and parallelisms with the structural engineer 
the following: sustainability, creativity and innovation, elegance and good detailing, value and ease of constructability. ${ }^{17}$ IABSE, on the other hand, created the Outstanding Structure Award to recognize "some of the most remarkable, innovative, creative, or otherwise stimulating structures". ${ }^{18}$ IABSE also considers sustainability and respect for the environment as important elements to be considered when judging structures. Similarly, the American Society of Civil Engineers (ASCE) has designated more than 200 projects from all around the world as "Historical Civil Engineering Landmarks". 19 To be designated, the project must be at least 50 years old, must illustrate the creative and innovative spirit of civil engineers, and represent "the achievement of what was considered an impossible dream." In this work, the authors consider the idea of "outstanding quality" broadly to include also the journeys of engineers who opened significant new paths in the profession and/or whose work had a special social impact.

The journey of the structural engineering hero, and the measure of its success (quality), is described in detail via the three Acts of the hero: Departure, Initiation and Return. Note that every hero has his/her unique journey and that these journeys do not necessarily follow all the stages of Campbell's monomyth.

\section{Act 1. Departure}

For a structural engineer, the call to adventure is the request to undertake a new project like a bridge, a roof or a building. In the hero's journey, the hero must escape the Ordinary World and face the unknown. For an engineer, facing the unknown can be designing a structure with a new structural type, shape, material or going taller, longer or wider than he/she ever did. For example, Othmar Ammann (1879-1965) finished the George Washington Bridge (Fig. 2) in 1931 with a main span of $1067 \mathrm{~m}$, a span that nearly doubled the previous world record for the longest span (i.e. $564 \mathrm{~m}$ of the Ambassador Bridge in Detroit completed in 1929). Similarly, Eduardo Torroja (1899-1961) completed the Frontón de Recoletos in Madrid, Spain (Fig. 3) in 1935. The project included a concrete shell roof of unprecedented dimensions with a completely new shape that required solving a system of fifty-four differential equations and making and testing a reduced scale model of the roof (see Ref. [20] for more details). Both, Ammann's bridge and Torroja's roof soon achieved the rank of engineering masterpieces.

One of the stages included by Campbell in the departure Act is the refusal to the call where "we encounter the dull case of the call unanswered; for it is always possible to turn the ear to other interests". 11 Similarly, engineering heroes warn us of the kinds of structures that one should avoid designing. Pier Luigi Nervi (1891-1979) writes

Structural architecture of today, like that of the past and always, must give the impression of a stable and tranquil equilibrium rather than that of an astonishing, if not frightening, marvel of acrobatic exercise. Daredevil construction acrobatics, encouraged and made possible by present-day materials and calculating methods, at best must be limited to temporary structures with precise publicity goals such as exhibitions. $^{21}$

Similarly, Felix Candela (1910-1997) warns us of "pseudo-structural forms, totally deprived of logic and sense of equilibrium". 22

The call to adventure can also be associated to the vocation to become an engineer and, in that case, the potential hero might not answer the call owing to social and/or legal circumstances as exemplified by the difficulties encountered by women wanting to study engineering and to develop their careers. For example, the first women civil engineers graduated in the USA in 1876 (Elizabeth Bragg, 1858-1929), in Portugal in 1894 (Rita de Morais Sarmento, 1872-1931), in Ireland and the United Kingdom in 1906 (Alice Perry, 1885-1969), in India in 1953 (Shakuntala A. Bhagat, 1933-2012) and in Spain in 1973 (Carmen de Andrés). In France, women first entered the École des Ponts et Chaussées in 1959 and the École Polytechnique in 1972. Similarly, racial discrimination could also act as a motivation to refuse the call. To this respect, it is interesting the following comment included in the December 1922 issue of "The Crisis", a successful magazine published by the National Association for the Advancement of Colored People (NAACP) in the US: "Sometimes persons write to ask if it is worthwhile for a colored boy to study engineering. We always reply: 'Yes. He will have a hard time getting a job, but it can be done"., ${ }^{23}$ The article then continued to describe the successful career of Charles S. Duke, an African American civil engineer. Note also that the article, even though written by a woman, did not

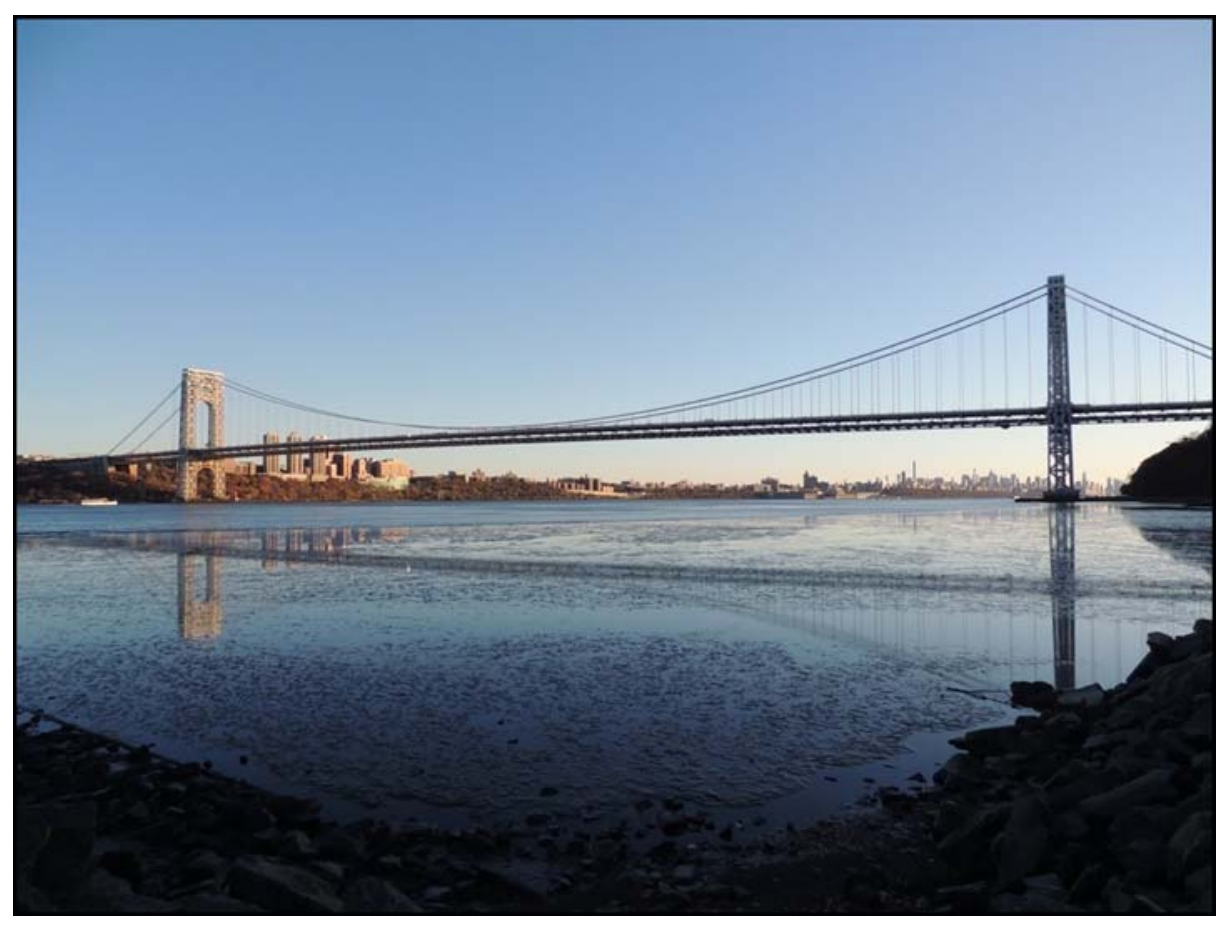

Fig. 2: George Washington Bridge (1931) over the Hudson River. Main engineer: O. Ammann. Image: M. Garlock 


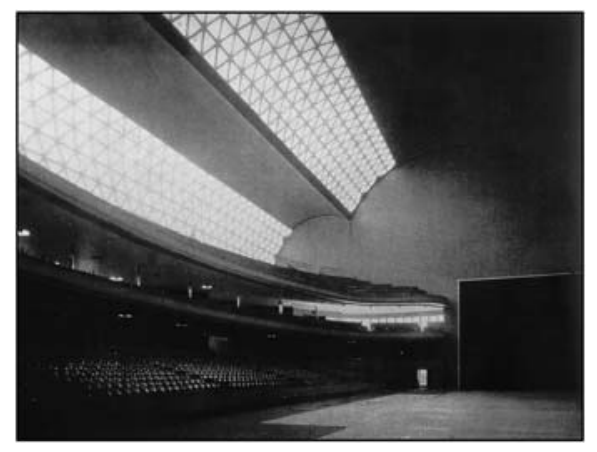

Fig. 3: Frontón Recoletos (1935) in Madrid, Spain. Engineer: E. Torroja; architect: S. Zuazo. (Image courtesy of Archivo Torroja, CEHOPU-CEDEX)

consider the possibility of African American women going to engineering schools.

However, the hero is not alone. According to Campbell, another stage of the monomyth is the supernatural aid, a first encounter with "a protective figure ... who provides the adventurers with amulets against the dragon forces he is about to pass"11 and inspires the hero finally to answer the call. This would be the case, for example, of Yoda in Star Wars. Engineering heroes also receive help from important protective figures who serve as inspiration: the masters from the past. For example, the engineer Jean Rodolphe Perronet (1708-1794) mastered the design of stone bridges in the eighteenth century and chamfered the edges of the stone arches to improve water flow through them. This feature, called "corne de vache" (cow's horns), has inspired many others such as Thomas Telford (1757-1834), who used it in his Over Bridge, François Hennebique (1842-1921) who used it in his Risorgimento Bridge (Fig. 4a) or, more recently, M. Guisasola, who has made the "corne de vache" a distinctive component of his designs (Fig. 4b).

Being committed to the journey, the hero moves into the crossing of the first threshold where the "threshold guardians" can be found. "Beyond them is darkness, the unknown and danger". ${ }^{11}$ The first threshold thus marks the beginning of the journey. For the engineering heroes, this stage could be represented by the first ideas and sketches for a specific project. For example, Fig. $5 a$ shows a first sketch done by José Romo for a proposal for a design competition for a new bridge close to the Roman

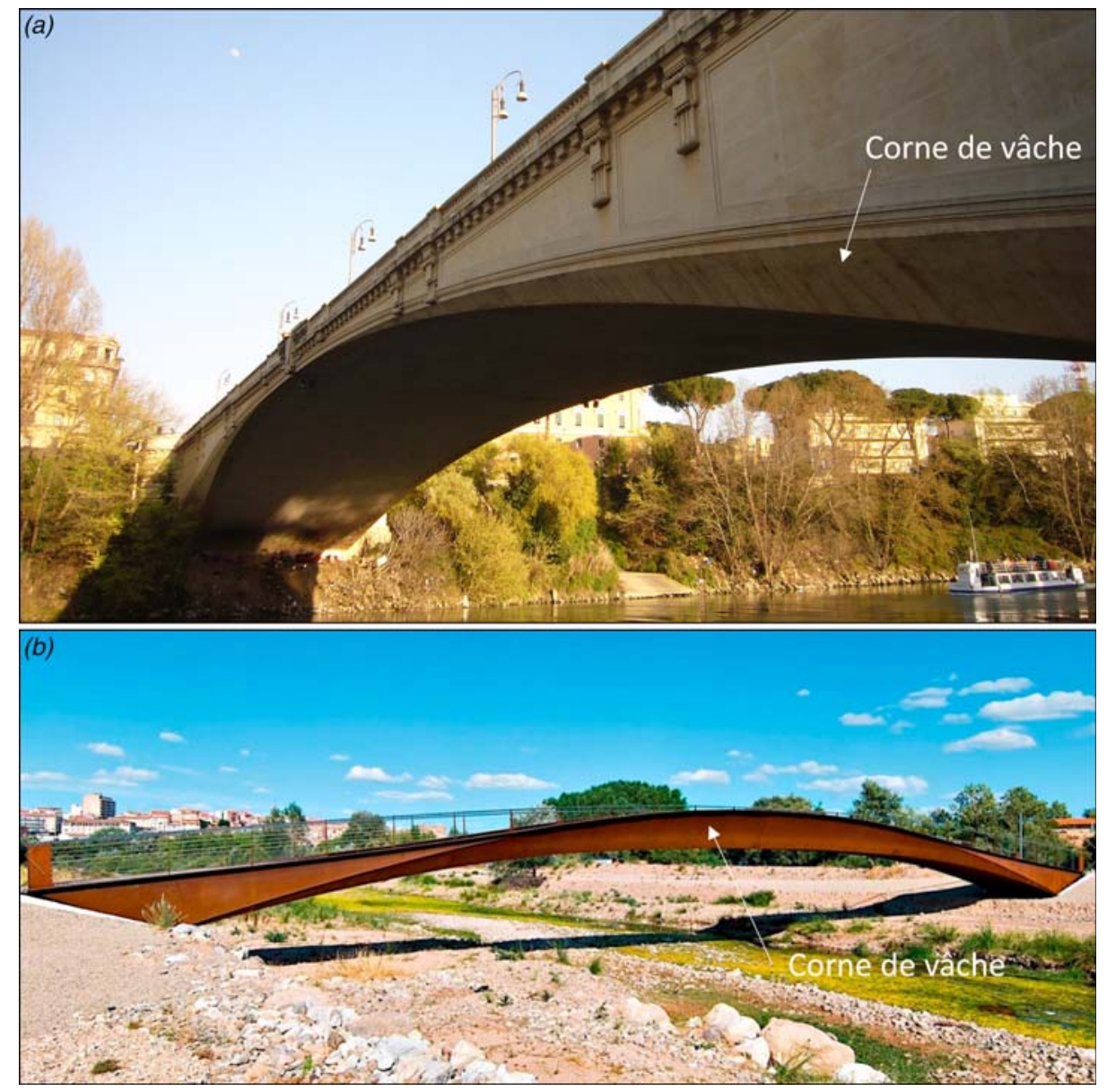

Fig. 4: (a) F. Hennebique's Resorgimento Bridge (1911) over the Tiber River in Rome, Italy. Image: I. Paya-Zaforteza. (b) M. Guisasola's Calahorra Footbridge (2007) over the Cidacos River in La Rioja, Spain. Image: José Manuel Cutillas (courtesy of Anta Ingeniería Civil)

Alcantara Bridge (AD 106) in Southern Spain. The proposal is shown in Fig. $5 b$ and was inspired by the Lascellas Bridge (1860, Fig. 5c) providing more evidence of the importance of construction history and the everlasting power of past constructions.

\section{Act 2. Initiation}

After crossing the threshold, the hero encounters trials, temptations and enemies, but also allies. There is even a point where he/she endures a supreme ordeal and faces death, although finally he/she will overcome all problems and achieve the goal of the quest, finding "the elixir of Imperishable Being." 11

Designing an outstanding structure is not an easy task and requires overcoming many challenges of different natures, which are the equivalent to the trials, tests and temptations of the hero. There can be economic problems associated with an external crisis as was the case for the George
Washington Bridge (Fig. 2) built during the Great Depression (19291939) resulting in the elimination of the intended granite cladding on the towers. Sometimes, challenges can come from the technical complexity of the work and strict time constraints. This was the case for the Munich Olympic Stadium roof (Fig. 6), a spectacular design whose cost estimate increased by more than ten times above the estimate before construction began ${ }^{24}$-likely due to knowledge gaps and lack of existing experience when the design was proposed. These knowledge gaps required gigantic developments in fields such as scale models, numerical analysis and geodetics to make possible a roof that many thought would be unbuildable. ${ }^{25}$ At other times, the challenges can be administrative. For example, and according to his biographer J.A. Fernández Ordóñez, ${ }^{26}$ the engineer Eugène Freyssinet (1879-1962) had problems with the public agency in charge of building the viaduct over the Bernand (1913), a railroad arch bridge with a main span of $170 \mathrm{~m}$ that 
would have been a world record in concrete bridges. The complexity of the work made the agency request a technical report from a committee. However, the committee refused to take any official responsibility for the work and passed this responsibility to Freyssinet, who assumed it without any hesitation. Unfortunately, only the foundations and half of the scaffolding were completed before the project was cancelled owing to World War I and subsequent challenges unrelated to the design. ${ }^{26}$

The journey also makes the hero encounter enemies-probably the most powerful enemies in structural engineering are nature and wars. Nature personified, for example, by wind loads was responsible for the collapse of some bridges in the past such as the Wheeling Bridge in 1854, a span length world record suspension bridge, and the Tacoma Narrows Bridge in 1940. While the latter example points to a lack of knowledge of wind dynamic effects on long-span bridges, this phenomenon had been observed in historical cases dating back to the nineteenth century but forgotten to history with an overreliance and confidence in the mathematical theory (in this case, deflection theory) that was commonly used in the design of long-span bridges at that time. ${ }^{27}$ After the Tacoma collapse, several major suspension bridges in the US were strengthened to prevent a similar failure. For example, a bottom horizontal truss was added to the deck of the Golden Gate Bridge to create a closed section much stiffer in torsion than the original design (Fig. 7).

Wars are another major enemy of structures. For example, Le Veurdre Bridge (1910) over the Allier River in France, designed and built by Freyssinet, was destroyed in 1940. Fortunately, Freyssinet created a "younger brother" bridge near Vichy, the Boutiron Bridge (1913), which still in service today (see Fig. 8). Other examples of representative bridges destroyed by wars are the Hohenzollern bridge in Cologne, Germany, which was destroyed in 1945, and the Mostar Bridge, Bosnia and Herzegovina, which was destroyed in 1993. Other major structural engineering works that disappeared as a consequence of wars are Freyssinet's Orly hangars, Nervi's Orvieto and
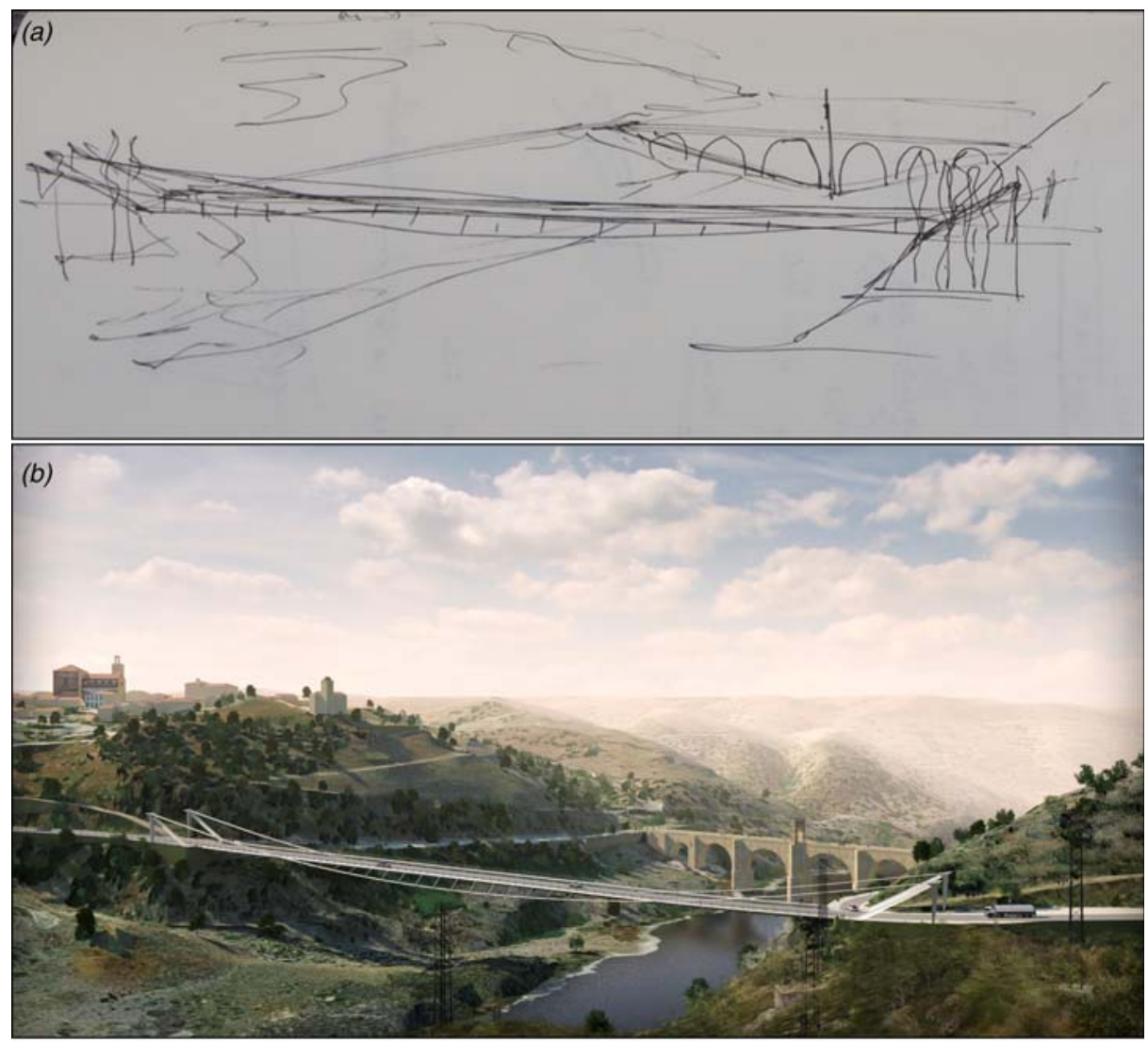

(c)

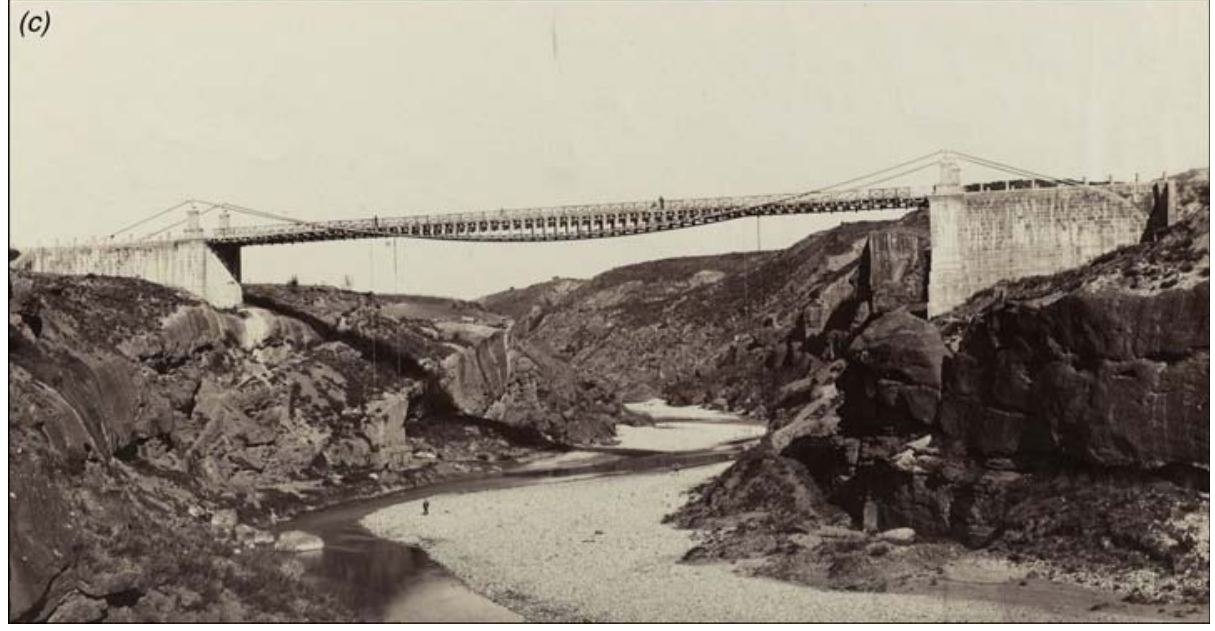

Fig. 5: Proposal for a design competition for a new bridge close to the Roman Alcantara Bridge (AD 106) in Southern Spain: (a) hand-drawn sketch by the engineer J. Romo; $(b)$ render of the final proposal (courtesy of Fhecor Ingenieros Consultores); (c) inspiration for the proposal: Lascellas Bridge in Huesca, Spain (destroyed on 21 July 1936 during the Spanish Civil War). Image: J. Laurent

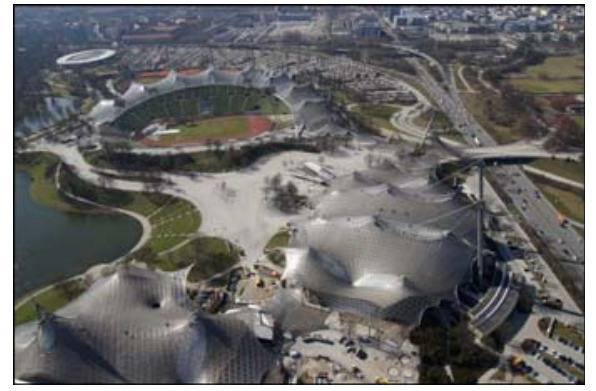

Fig. 6: Aerial view of the roof over the buildings of the Olympic Park, Munich, Germany, 1972. (Courtesy of Nicolas Janberg, Structurae)
Orbetello hangars and Torroja's roof for the Frontón Recoletos. Wars can destroy structures, but the hero can use engineering to reduce their effects by rebuilding or to prevent them by "dismantling borders" and bringing people closer, as Tung-Yen Lin (1911-2003) did. ${ }^{28}$ Lin was a Chinese American visionary engineer responsible for many advances in the theory and practice of prestressed concrete. He considered technology as a means of diplomacy and, during the Cold War, he invited a Soviet Union 
delegation to a world conference on prestressed concrete held in 1957 in San Francisco. The next year he visited the Soviet Union following an invitation to the conference advisory committee, and one year before cultural exchanges began. By that time, he also started a technical exchange between the US and China when these countries had only exchanged ping-pong players previously. In 1958, he introduced his most ambitious and boldest project, the "Intercontinental Peace Bridge," aimed at connecting the Soviet Union and the US over the Bering Strait. In 1988, Lin considered that the crossing did not present any real problem, and estimated its cost would be in the region of $\$ 4$ billion, considering this cost to be "indeed small when compared to the defense costs of the two superpowers, which are now well over $\$ 600$ billion per year". 29

More uncommon is for the structural engineer to find enemies within the profession. Collaboration is promoted by engineering associations and the heroes have shown a generous character as explained in the Section "Characteristics of a Hero". However, "surviving" in the highly competitive engineering world is not an easy task and some rivalries have existed between celebrated structural engineers: Robert Stephenson (1803-1859) and Isambard K. Brunel (1806-1859), as well as David B. Steinmann (18871960) and Othmar Ammann for example. $^{16}$

Finally, enemies can also be found in public opinion. For example, Billington $^{30}$ describes how Robert Maillart's first important work, the Stauffacher Bridge (1899) over the Sihl River in Zurich, Switzerland, had its three-hinged arch covered with fake stone walls to satisfy an urban taste that preferred stone bridges. Similarly, it is well known that the Eiffel Tower (1889) was criticized by a group of eminent artists who wrote an open letter on 14 February $1887^{31}$ to Jean Charles Alphand, civil engineer and chair of the works for Paris 1889 Universal Exhibition. In their letter, the artists described the tower as a

Vertiginously ridiculous tower dominating Paris like a gigantic factory chimney, crushing with its barbarian mass Notre-Dame, the Sainte-Chapelle, the dome of the Invalides, the

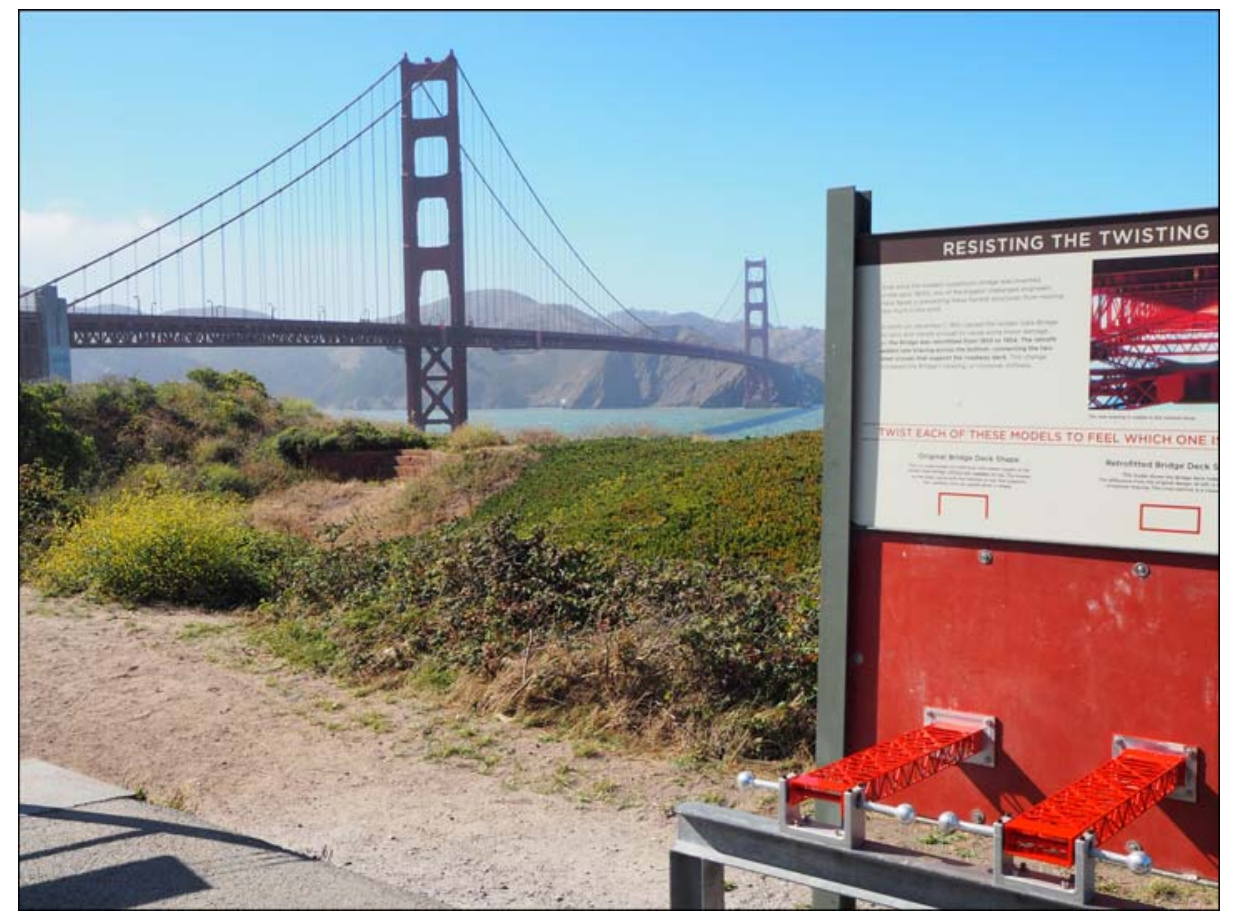

Fig. 7: Golden Gate Bridge. General view and explicative panel at the Golden Gate Bridge exhibition showing two scale models of a portion of the bridge deck. The one on the left is the original open section. The one on the right is the retrofitted section. Image: I. PayaZaforteza

Arc de Triomphe, all our monuments humiliated, all our architectures shrunk will disappear in this stupefying dream.

It is also well known that their letter had no effect, the Tower was completed and became a popular and financial success, a symbol of Paris and a symbol of a new aesthetic vision.

But in addition to enemies, the engineering hero also counts on the support of some allies for his/her journey. These allies could be mentors (see e.g. Ref. [32]), other colleagues, engineering associations, books, articles and, of course, the World Wide Web, wherein many resources are available. For example, Freyssinet wrote the following in

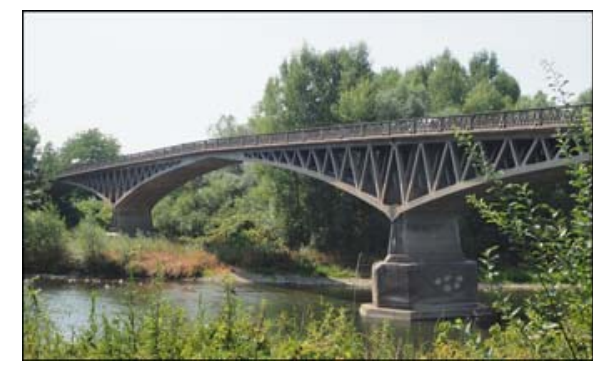

Fig. 8: E. Freyssinet's Boutiron Bridge (1912) over the Allier River in Creuzier-leVieux-Charmeil, France. Image: I. PayaZaforteza reference to the eminent engineers Jean Résal (1854-1919), Paul Séjourné (1851-1939) and Charles Rabut (18521925): me into contact with three renowned engineers who were, above all, great artisans with an enthusiasm for their work: Résal, Séjourné, Rabut. Their hearts, I felt, beat in common with mine and I owe an eternal debt to these men who remained friends and

In the hero's journey, he/she also must confront his/her fears, face death and could even die just to be reborn. These steps are necessary to achieve the goal of the quest. In the context of the structural engineering hero, the main fear could be associated with the collapse of the structure, as previously explained for example by the Tacoma Narrows case; but bankruptcy is another potential "death". At the age of 50, Freyssinet was a very well established engineer, technical director and partner at Limousin \& Cie. He decided to quit this company to focus during five years (1929-1933) on the development of prestressed concrete electric pylons. The business decision was catastrophic from a financial point of view and Freyssinet was ruined. However, this experience set
The Ecole des Ponts et Chaussées put guides until their death. ${ }^{33}$ 
the basis for the techniques he would use later on to consolidate the foundations of the Le Havre Maritime Terminal (1934), whose success provoked the fast and widespread use of prestressing. ${ }^{33}$ This made Freyssinet consider the failure of his electric pylons business "to be more valuable to me than the memory of my finest successes". 33 Sometimes the engineering hero physically died during the quest. It happened to John A. Robling (1806-1869) designer of the Brooklyn Bridge who died because of the injuries caused by an accident suffered while he was preparing the bridge construction site. However, J.A. Roebling was "reborn" in the figures of his son Washington A. Roebling (1837-1926) and his daughter-in-law Emily Warren Roebling (1843-1903) who finished the bridge (see details in Ref. [34]). The case of Emily Warren is especially significant since she might probably be the first known bridge heroine in history. Sometimes the hero does not die physically but he/she has a premature retirement. This was the case for many civil women engineering pioneers such as Dorothy Donaldson Buchanan (1899-1985). Buchanan was the first female member of the Institution of Civil Engineers in 1927 and worked on the design and construction of works such as the Sidney Harbour Bridge and the Silent Valley Dam in Northern Ireland. She retired from the profession in 1930 after her marriage because she thought she could not be both a successful wife and civil engineer. ${ }^{35}$ However, the professional spirit of Buchanan lives in the many women taking her as an inspiring example and "protective figure" to pursue a career in civil engineering (see e.g. Meshi Taka ${ }^{36}$ ). These women make true Buchanan's statement "I felt that I represented all the women in the world. It was my hope that I would be followed by many others". 37

Facing death and failing can be represented by other facts, such as: (a) a design competition not won as was the case for the design shown in Fig. $6 b$; (b) a project where some important features are modified during construction as happened to the cladding of the towers of the George Washington Bridge; or (c) a structure designed but not built as happened for the last project of the Strait of Messina Bridge. In this latter case, sometimes a design is not built because it is too advanced and thus too risky in terms of safety, cost or construction time for its period. For example, the CASA factory roof designed by $\mathrm{E}$. Torroja in 1938 for an aircraft manufacturer was formed by a series of vaulted shells only $5 \mathrm{~cm}$ thick connected to parabolic arches spanning $81.4 \mathrm{~m}$ (Fig. 9) and was $20 \%$ more economical than a traditional design that made use of trusses. However, Torroja's proposal was never built. According to him, this happened because "perhaps ... it seemed too revolutionary". 38 Details and a structural analysis of this extraordinary and unknown work can be seen in Ref.[39]. It is important to note that the concept of "failing" is also subjective: where some could see a fail, others can see a gift. For example, the George Washington Bridge with its distinctive naked towers was considered by Le Corbusier (1887-1965) as "the most beautiful bridge in the world" and "the only seat of grace in a disordered city (=New York)" ${ }^{40}$

Finally, the hero receives his/her reward: seeing the bridge (or the designed structure) completed and in service. This is a moment of profound personal satisfaction. Freyssinet summarized this feeling when he wrote "I was born a builder. It was for me both an overriding need and also an endless source of joy imposing upon the crude material those shapes and forms which sprang from my own imagination". 41 The reward also has an important universal social perspective that makes even a simple structure very gratifying. The words of Avery Bang, engineer and CEO of the non-profit organization Bridges to Prosperity (B2P), which has built more than 350 trail bridges serving over 1.2 million people in poor rural isolated areas, summarize this perspective:

Poverty due to rural isolation is a crisis that we can solve in our lifetime, but it is not about the bridges. It's about Angelique in Uganda saving hours off of her walk to safe potable water, it's about Mina in Nicaragua, a community health worker who can finally reach everyone in her community, and it is about Rosa, a mother in Bolivia who doesn't have to make the impossible choice between educating her daughter and keeping her safe, because that is the power of connection. ${ }^{42}$

The reward can also come in the form of recognition, sometimes even posthumously. This was the case of Nora Stanton Blatch Barney (1883-1971), the first woman to become a member of the ASCE. She sued this organization in 1916 when she lost her membership when passing the junior status age limit and was denied the associate membership. She lost the lawsuit, but the ASCE gave her Fellow status posthumously in 2015. Similarly, Buchanan's official recognition came in 2019 when the ICE dedicated a room to her at its headquarters.

\section{Act 3. Return}

After finishing the work, and enriched by the journey, the hero comes back to the Ordinary World where he/she can share the gained knowledge with his/ her fellow men through lectures, seminars, conferences, articles, workshops, books, etc. The completed work with its history will stand as a live learning space and the hero will use the wisdom gained in a new journey, just by starting a new project! This

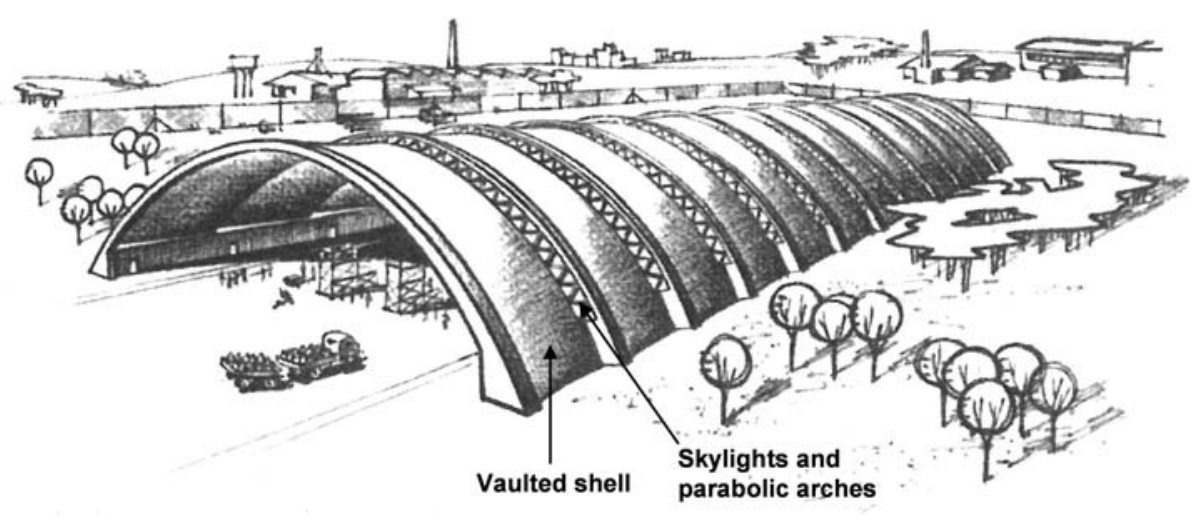

Fig. 9: CASA factory roof. Sketch showing a $3 D$ view of the roof designed by Torroja for the CASA Factory (source: Torroja ${ }^{38}$, courtesy of Archivo Torroja, CEHOPU-CEDEX) 
wisdom is not related only to technical matters, since the journey makes the hero also develop other types of skill. For example, Ammann had to work more like a politician than as an engineer to promote his vision for the George Washington Bridge at both sides of the Hudson River. ${ }^{28}$ Torroja might have developed his entrepreneurial skills when he created the company "Investigaciones de la Construcción S.A." (Research on Construction Co.), specializing in the development and testing of reduced scale models of structures such as the Recoletos roof. Bang started her bridge building career as a volunteer university student in 2006, when she led a team that built a bridge in Peru with B2P. More than a decade later, she was the president and $\mathrm{CEO}$ of $\mathrm{B} 2 \mathrm{P}$, where she had developed entrepreneurial skills and transformed the organization from a $\$ 120,000$ budget in 2006 to a current budget of more than $\$ 6$ million, from solving specific isolation problems to solving problems at a higher scale (e.g. a district or a country) as in Rwanda, where B2P oversees the construction of over 350 footbridges to meet this country's entire identified needs. ${ }^{43}$

\section{Characteristics of a Hero}

A hero is "a person admired for bravery, great achievements or good qualities". 44 Can outstanding structural engineers possess hero characteristics? In the best structural engineers (the engineer as hero), one notices characteristics that are common to both and can be defined by four "P"s: they are prepared, they are planners, they have (super) powers, and they are persona grata. Each of these

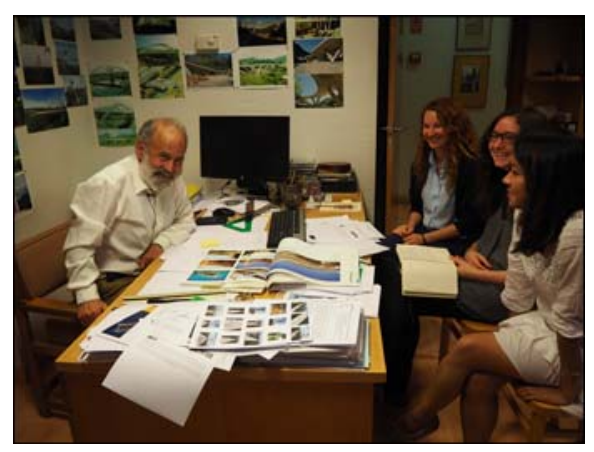

Fig. 10: Leonardo Fernández. Troyano at his desk sharing a conversation with some students. Image: I. Paya-Zaforteza characteristics is elaborated in the subsections that follow.

\section{Heroes are Prepared}

Heroes prepare for the new adventure by arming themselves with special objects. In the monomyth, the hero might have a magic wand, for example. These special objects for structural engineers are the tools of design and education. Fig. 10 shows the desk of Leonardo Fernández Troyano, an internationally renowned bridge engineer. A detailed insight into the picture reveals some of the special objects the bridge hero uses. One can find: (a) images of some of his built works that represent his own experience; (b) books, journals and technical brochures that represent scientific and technological knowledge; and (c) a computer, a calculator, sheets of paper, pencils and rulers.

A subtle but important point must be made: the use of rulers, pencils and calculator enable the hero to sketch a conceptual design and then to check its feasibility by hand calculations. For example, Fig. 11 shows the preliminary hand calculations carried out by J. Romo for the design shown in Fig. $5 b$. Through simple formulas and analyses, the horizontal reaction at the supports of the main cable, the compression in the pylon and the required area of steel in the pylon are obtained. Then a shape is given to the cross

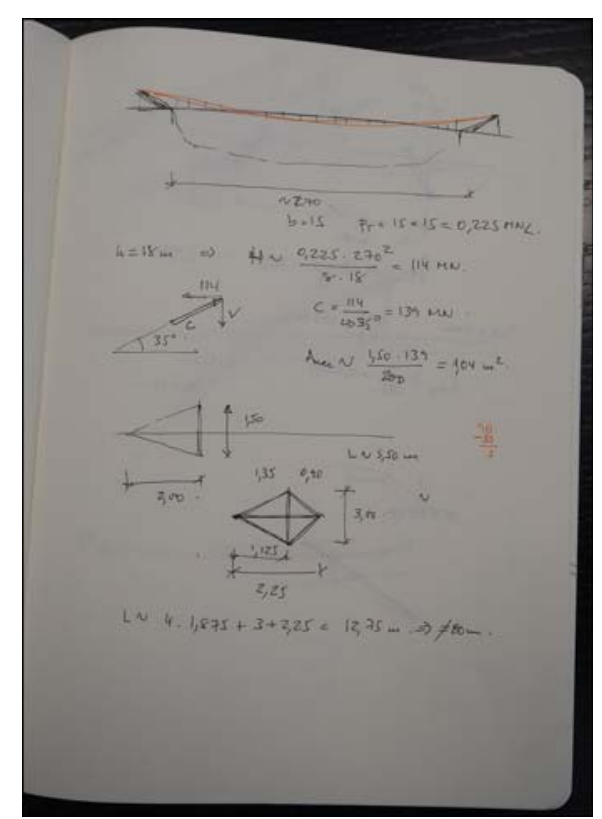

Fig. 11: José Romo's notebook showing the preliminary hand analysis of the design displayed in Fig. $6 b$ section of the pylon in agreement with this area.

Summarizing, the structural engineering hero starts with an idea ("before and above any structural analysis, there is an idea that shapes the material in a resisting form" Torroja wrote in Ref. [45]) that is then checked with some simplified calculations. The final design will be the result of the evolution of this idea refined by the detailed calculations and the interaction with the context and with all the actors involved in the design and construction process. It is important to note that the use of hand calculations does not mean that the hero does not master the analysis. At this point, clarification is provided in the statement made by Carlos Fernández Casado (1905-1988), another eminent structural engineer (and father of Fernández-Troyano), who used to say "One must dominate the analysis so that the analysis does not dominate you". 46

Heroes are also prepared by reflecting on lessons from previous journeys and experiences. Reflection understood as a deep thinking about the hero's own work or about others' work is key. Travelling is thus crucial, since it enables the hero to see first-hand the evolution of his/her own works and to visit others' structures, providing fundamental information to improve future designs. For example, Fig. 12 shows Maillart reflecting on his design of the Salginatobel Bridge. He considered that the bridge was not

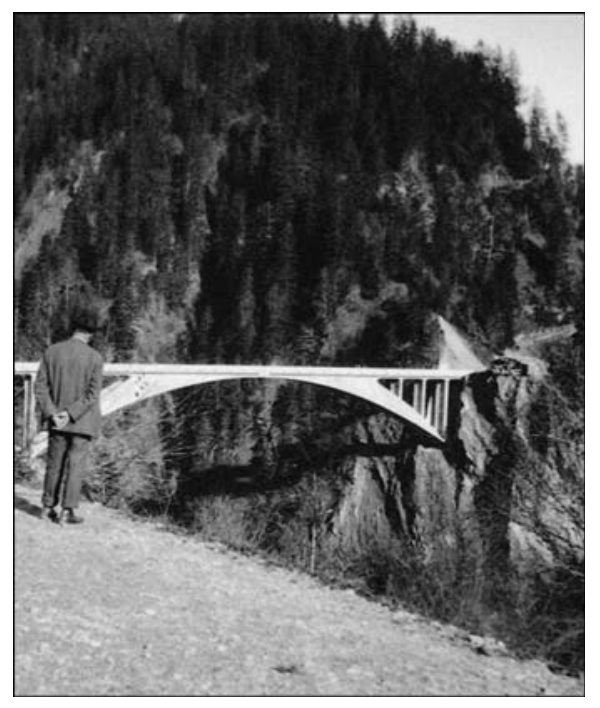

Fig. 12: Robert Maillart reflecting on the design of the 1930 Salginatobel Bridge. (Courtesy of Princeton University Maillart Archive) 


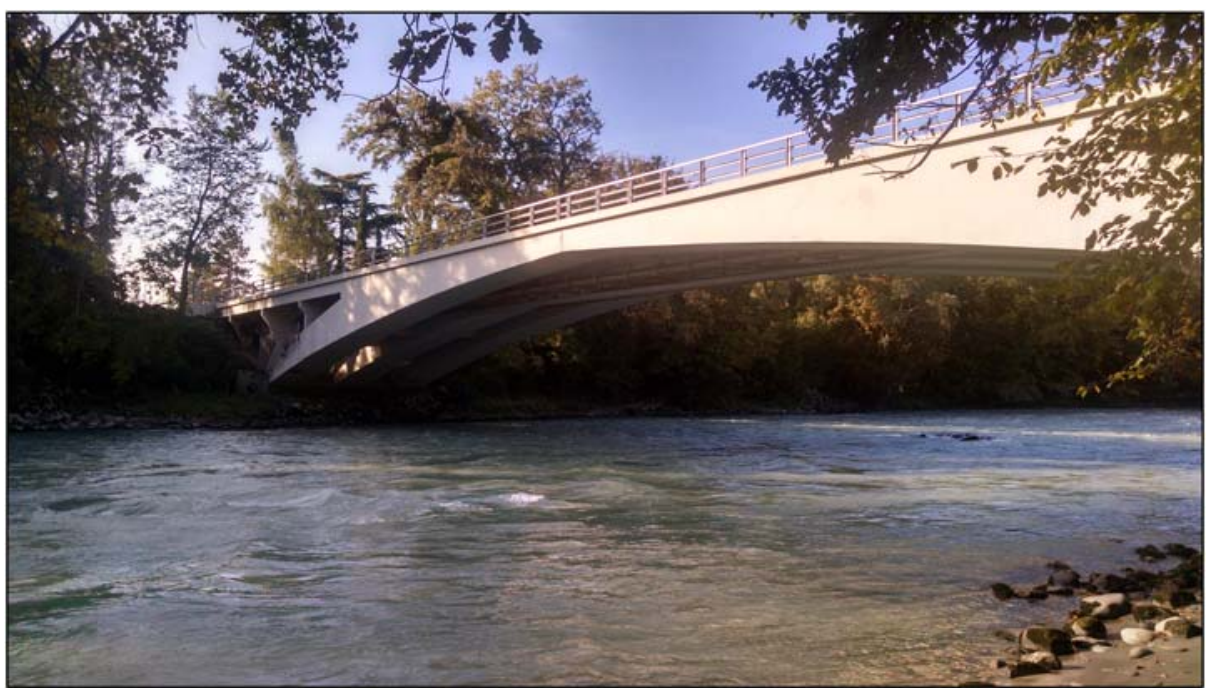

Fig. 13: R. Maillart's Vessy bridge (1937) over the Arve River in Geneva, Switzerland. The underside of the arch is not a continuously smooth curve from abutment side to abutment side like in Salginatobel, which enabled Maillart to express visually the discontinuity created by the hinge at the crown. Image: M. Garlock.

sincere because the form did not properly reflect the hinge that is located at midspan - and this reflection led to a new form of three-hinged concrete arch bridge referred to as the broken arch, ${ }^{47}$ which has a slight discontinuity at the arch crown as represented by the Felsegg Bridge (1933) or the Vessy Bridge (1937) (Fig. 13).

Reflection makes the hero extract important lessons from failures and even transform an initial failure into a success. For example, Freyssinet's Orly hangars were the result of a mistake made when the project was studied initially. ${ }^{48}$ The company had little time to prepare the competition and the bid presented was extremely low, so the construction part of the business was going to be ruinous. To save the business, and after much hard work, Freyssinet created new forms buildable with a single formwork that moved horizontally and required only a small amount of construction materials and labour. The project was finished at a profit. A deeper insight into the role of failure in engineering can be found in Petroski ${ }^{49}$ and is not developed here.

Finally, heroes might prepare by knowing the culture and people of his/her journey to get some familiarity with the Special World and reduce challenges and perils. In the structural engineering context, this means that the best engineers are educated in the arts and humanities, and thus are sensitive to the environment and aesthetics as related to their built work. For example, J. Schlaich played the violin and was a member of the Freie Universität Berlin orchestra while he was a student at the Technische Universität Berlin. At this institution Schlaich was also able to take courses on History, Philosophy and English Literature. $^{50}$ Heinz Isler (1926-2009), one of the masters of concrete shells, was an excellent drawer and watercolourist, and was even attracted to a career in painting, but the influence of his father, a geodetic engineer, lead him to study for a professional degree. ${ }^{30}$ Fernández Casado had degrees on Philosophy and Law in addition to his civil engineering degree. He was friend of the poet Federico García Lorca and the philosopher Xavier Zubiri. He was also a member of the vanguardist group that created the journal Gallo to claim a new art form for its time (the end of the 1920s). He was also the first engineer to become a member of the Royal Academy of Fine Arts of Spain.

With education and passion for the arts and humanities, the engineering heroes can respect settings and have a feeling for aesthetics. Scale is very important for the hero and the use of long spans is not an artificial feature to make a visual impact, but something justified by the context. Similarly, the hero has his/her own opinion about aesthetics, an opinion shared through writings, lectures and public discussion. For example, Nervi published the book "Aesthetics and Technology in Building", 21 the preface of which reveals his aesthetic "commandment": "the existence of a full and intrinsic agreement between aesthetic expression and the static and construction requirements or suggestions". Specific opinions on aesthetics are not uniform among all heroes and evolve with time, which is good for the richness of the built environment. The interested reader can find different perspectives on this topic from present-day designers, for example in Refs. [51-53].

\section{Heroes are Planners}

A monomyth hero often has a map detailing the steps to victory. Structural engineers' "maps" are defined by drawings and sketches. In Fig. 10, the tools of design, together with Fernández Troyano's brain and hands, represent the ability to imagine, sketch, draw and analyse. Eventually, construction drawings are made, which explain step-by-step how the structure must be built. To plan well, engineering heroes must know construction history. As explained in Ref. [54], construction history is a source of inspiration, esteem for the profession and creativity. Thus, it is logical that heroes share a deep knowledge and appreciation for the past. For example, Fernández Casado used to say that nobody should be allowed to design a bridge in Spain unless he/she had crossed the Roman bridge of Alcántara. Indeed, the eponymous design office that he created has a big picture of this bridge at its entrance. In fact, Fernández Casado studied and rehabilitated many Roman works, Segovia's aqueduct among them, and wrote many books and articles on Roman constructions. Similarly, Pier Luigi Nervi, called the first chapter of Ref. [21] "From the Past to the Present" and the influence of Roman construction is clear in his personal style (see Fig. 14). This influence of the past is also very present in current designs as shown by the contemporary examples of Figs. 4, 5.

To plan well, and make good construction drawings, the hero also pays major attention to the construction process. Many of the heroes of the past (Eiffel, Torroja, Freyssinet, Maillart, Nervi, Candela, Isler), worked as contractors or in very close partnership with contractors during a significant 


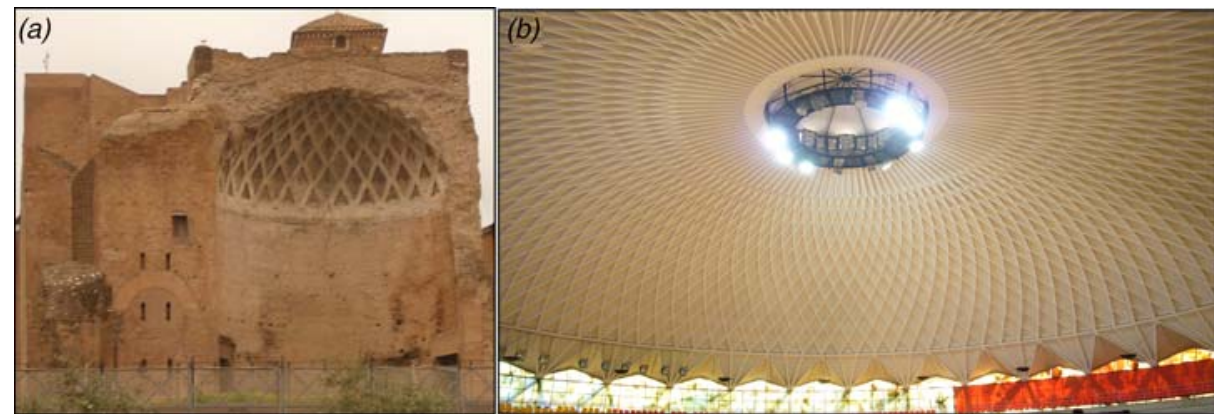

Fig. 14: (a) Temple of Venus and Roma, the Forum, Rome, Italy (AD 141); (b) P.L. Nervi's Little Sports Palace (1957), Rome, Italy. Images: I. Paya-Zaforteza

period of their professional life, being very often the owners of, or partners in, a construction company. This fact is reflected in their writings, which always insist on the importance of this stage. For example, Freyssinet declared that, even for the humblest projects, the definition of form required previous knowledge of construction means. ${ }^{26,55}$ Similar thoughts were expressed by Mauro Kawaguchi (1932-2019), engineer of structures such as the Fuji Group Pavilion for Osaka's 1970 Expo and the Sant Jordi Sports Palace for Barcelona's 1992 Olympic Games. Kawaguchi developed many innovations in space frames and pneumatic and domical structures (e.g. the "Pantadome System") and stated:

I think the construction method is very, very important in structural engineering. Some designers are enamoured of the behavior of a structure only after it is completed, but I think the way in which a structure is constructed is very important as well in terms of rationality and economy. ${ }^{56}$

Nowadays, the figure of the structural engineer who is also a contractor is more uncommon, but heroes are always in close contact with construction through, for example, participation in design and built competitions, collaborations with contractors on specific projects, and as technical advisors for institutions promoting works.

Finally, the planning process must look ahead to potential dangers and challenges, which often lie in the detail. Details are responsible for the good structural response of a bridge and for its adequate aging with minimum maintenance. Moreover, details are also key elements of the final aesthetics of the work. Freyssinet acknowledged the importance of detail when he explained the design process of one of the bridges built in his early career in the Moulins area (very probably his Le Veurdre Bridge):

After some hundred attempts, an idea leapt into my subconscious mind and imposed itself as being the only one possible. I then sketched the project down to its final details convinced that a work is good or bad precisely because of these details. ${ }^{33}$

Similarly, Fig. $15 a$ shows the Martutene footbridge (2016) in San Sebastián, Spain, designed by Mario Guisasola. ${ }^{51}$ All the details have been carefully thought out from the points of view of structural behaviour, aesthetics and durability (the bridge is in a very rainy area). The abutments are hidden, so the footbridge seems to spring from the soil. The deck is built with weathering steel so as better to blend with the landscape and to avoid corrosion problems. The main deck girders are also part of the handrail and the rest of the handrail has a minimalist design combining weathered and stainless steel. In addition, drainage details are completely integrated and they enhance instead of diminish the bridge's aesthetics (Fig. $15 b)$. The details of the deck design also enable an easy and imperceptible crossing of the Urumea River by utility pipes (Fig. 15c).

\section{Heroes Have (Super) Powers}

Superpowers are special talents and skills and are, in the case of a hero, used for good. An integration of creativity and courage is considered a superpower of the structural engineer because accepting the call to adventure and facing the unknown requires both creativity and courage, where creativity, sometimes, takes courage. Creativity means to find new solutions given constraints such as economy, span, time and resources. Examples of courage are to go taller, wider, longer and lighter, or to use a new structural system or construction material. This was expressed by one of Spain's most successful bridge engineers Javier Manterola when he said $^{57}$

We must have courage. You are lost if you wait to know everything about a bridge type before starting to use it in a particular design. ... You need to dare to do what you do not completely dominate, and, through this process, you will end up learning how things are done.

Being courageous and facing the challenge also implies taking risks. This can be scary but is also very stimulating. This idea is supported, for example, by the following statement by Manterola (made in reference to the Cádiz Bay Bridge, Fig. 16)

When you have not done anything so big before, either you take the risk or you do not take the risk. You are scared. This is a very clear feeling when you are going farther than you have ever been before. And this is very exciting. ${ }^{58}$

Juan Sobrino, an engineer who pioneered the use in bridges of new materials such as composites and stainless steel expressed himself in a similar way: "People are very practical. Everything is standardized. You go to the codes. There are flowcharts, but there is no engineering in that. There is no risk there, so there is no excitement". ${ }^{9}$

Courage can also be expressed as a strong commitment of the hero to his/ her convictions, which makes the hero speak out to defend them, no matter who might be on the other side. For example, in the 1990s, Jörg Schlaich publicly criticized the German railways (Deutsche Bahn, DB henceforth) and consulted with a professor who was an expert in planning legal procedures to see if he could sue the German government or the railways for "spoiling the country with ugly bridges". ${ }^{60}$ This critique did not stop him from working for DB. On the contrary, Schlaich's firm designed innovative and aesthetic bridges for DB such as the Havel Bridge in Berlin-Spandau (1997) and the Humboldt Harbor Bridge (2006) 

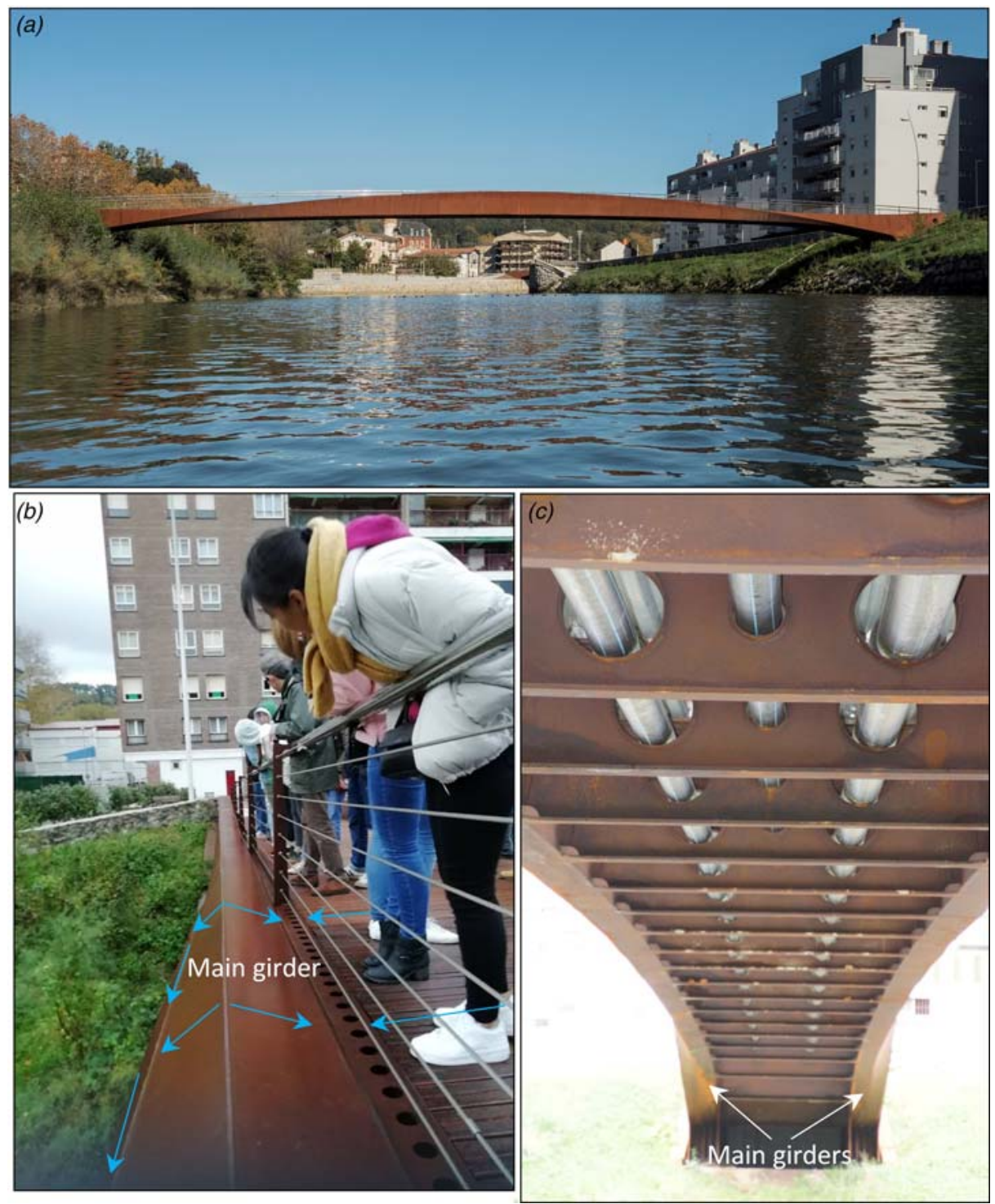

Fig. 15: Martutene Footbridge (2015), San Sebastian, Spain. Designer: Mario Guisasola. (a) Elevation. Image: Xavier Font (courtesy of Anta Ingeniería Civil). (b) Drainage systems. Blue arrows indicate water flow. Image: I. Paya-Zaforteza. (c) Bottom view of the deck showing circular voids in the transverse girders to enable hidden utilities crossings. (Courtesy of Nicolas Janberg, Structurae)

in Berlin (see Fig. 17). In addition, Schlaich was also crucial for the creation in 2007 of the "DB Brückenbeirat" (DB Bridge Advisory Council). This committee, integrated by Schlaich and a select group of engineers and architects, had the important missions ${ }^{61}$ of (a) intervening in very prominent projects to ensure that the final solutions were aesthetic, economic and functional, and (b) writing a set of guidelines for the design of railway bridges. Another example of commitment and courage is that of William Hunter Dammond (1873-1956), who graduated in civil engineering in 1893 and was one of the first African Americans to gain such a degree. Dammond worked as a sewer contractor, draftsman, teacher, professor and bridge engineer,
Americans in the professions of engineering and architecture ${ }^{64}$ (an argument with which $\mathrm{Du}$ Bois was in disagreement $^{65}$ ). In the final letter, ${ }^{66}$ Dammond was very critical of $\mathrm{Du}$ Bois for having commended actions in relation to the construction of the new church that were "racially disloyal in the extreme" and affirmed that he had not been hired for the structural design of the church due to his race and despite having been "complimented four times by experts in the engineering offices of the Brooklyn and Manhattan Building Departments".

Finally, another power of the hero engineer is his/her ability to communicate effectively, and persuasively. Since the hero is a master of the development of ideas, he/she has a clarity of mind that makes it possible to explain his/her designs in a simple way. Figure $18 a$ shows Peter Tanner using two bananas (one curved, one straight) to explain the structural behavior of La Paloma Footbridge (2010) in Madrid, Spain, a complex curved Cshaped truss. Figure $18 \mathrm{~b}$ shows an image of the completed bridge.

\section{Heroes are Persona Grata}

Heroes are persona grata-always welcome-not least because they are generous and exude joy via their passion and love for their work. Generosity is expressed in several ways. For example, it is demonstrated through articles, lectures and meetings with professionals and students where the hero shares his/her wisdom. This is exemplified by the work of the structural engineer Roma Agrawal, who designed the foundations and spire of

and developed several patents that improved the safety of railways and saved lives. ${ }^{62}$ In 1923, Dammond engaged corresponded with William E.B. Du Bois (1868-1963), a renowned sociologist, historian, civil rights activist and first African American to earn a Ph.D. from Harvard University. Du Bois was also the editor of the NACCP magazine The Crisis and requested a photograph of Dammond as well as information about a church he was about to erect in Harlem, New York. ${ }^{63}$ Dammond clarified that he was not erecting the structure but in charge of " some of the creative activities that precede ... erecting ... I am not a mechanic: I am a civil engineer". ${ }^{64}$ Dammond also refused to attend Du Bois' petition because he was not properly recognizing African

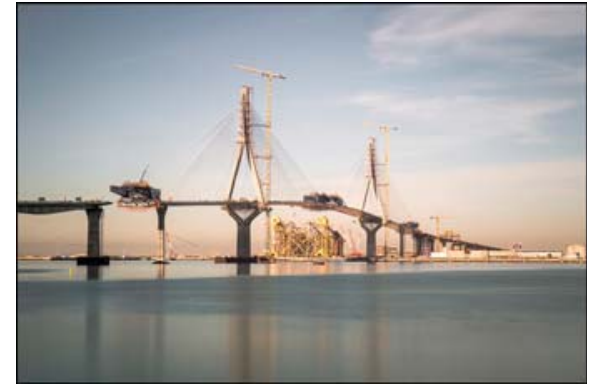

Fig. 16: Cádiz Bay Bridge (2015) in Cádiz, Spain. Main span: 540 m (Spain span length record). Design engineers: J. Manterola, A. Martínez, M.A. Gil Ginés, J. Antonio Navarro, S. García, S. Criado, B. Martínez, L. Blanco, R. González and G. Osborne. (Courtesy of Carlos Fernández Casado S.L.) 

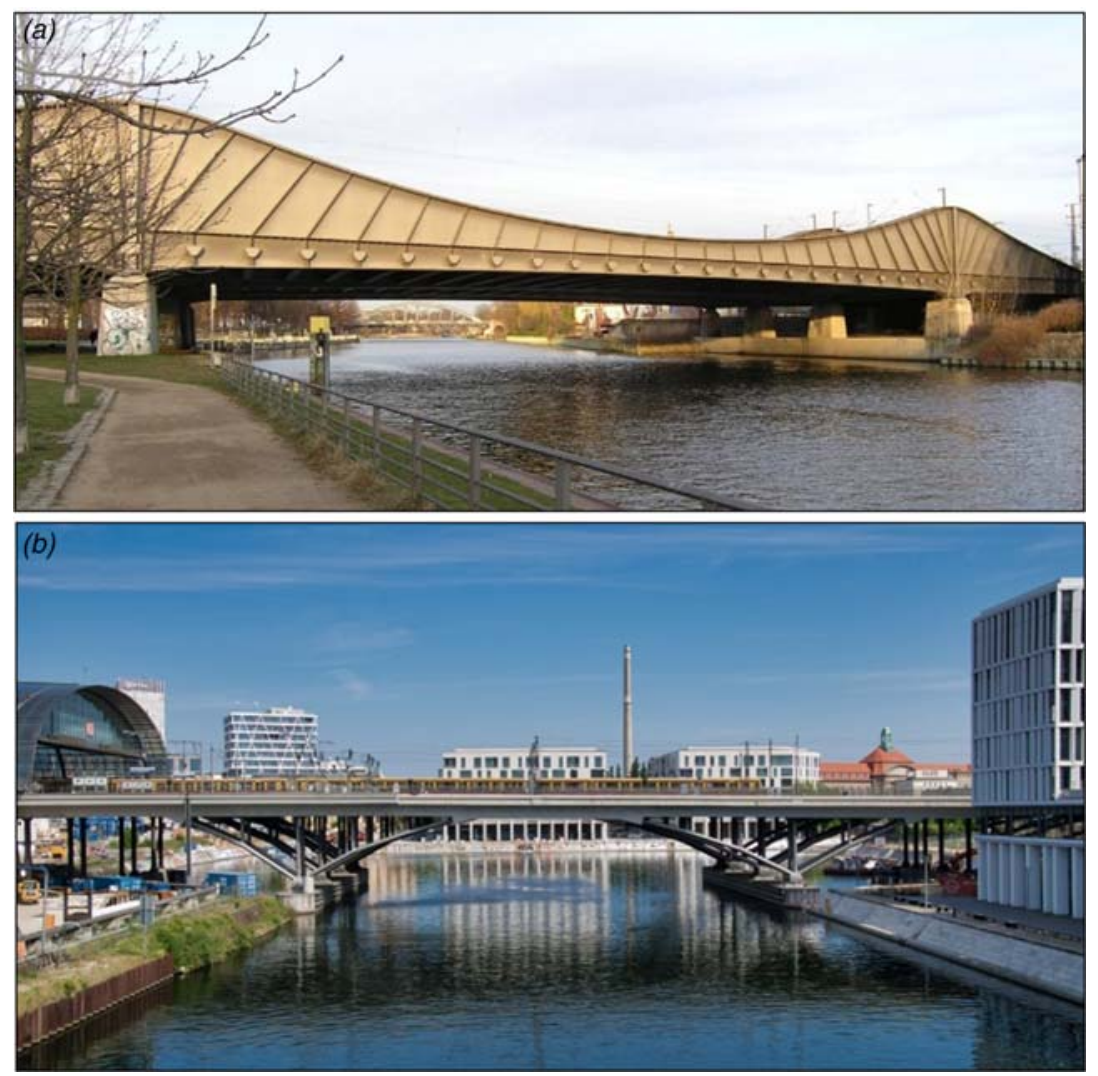

Fig. 17: (a) Haveln Bridge in Berlin-Spandau, Germany (1997) (courtesy of Inge Kanakaris-Wirtl, Structurae); (b) Humboldt Harbor Bridge (2006) in Berlin, Germany (courtesy of Nicolas Janberg, Structurae). Both bridges designed by J. Schlaich and H. Schober, sbp
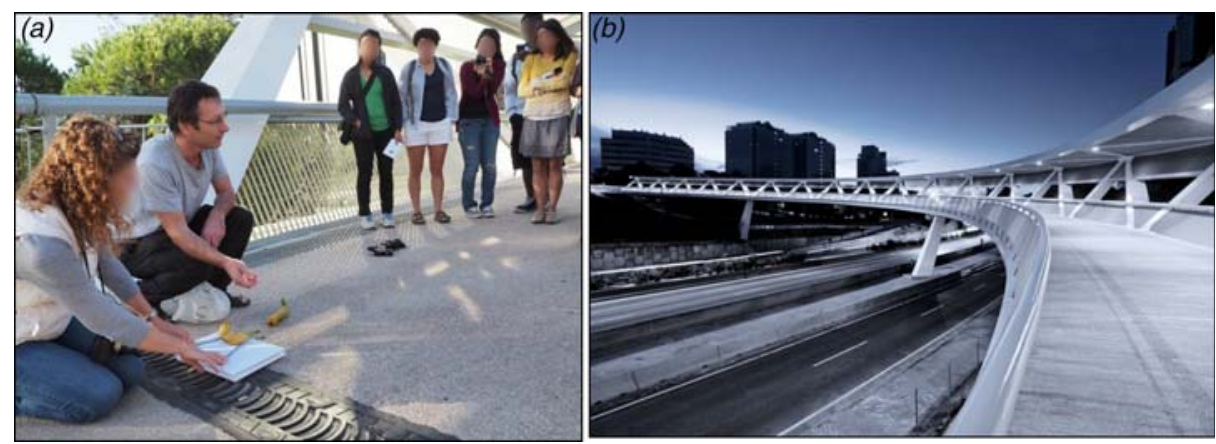

Fig. 18: (a) P. Tanner using two bananas to explain to a group of students the behaviour of La Paloma Footbridge. The explanation is done on the bridge itself. Image: I. PayaZaforteza. (b) Image of the bridge (courtesy of Paco Gómez and Cesma Ingenieros)

The Shard-one of the tallest buildings in Europe. She promotes engineering, scientific and technical careers to young people with a special focus on under-represented groups through books, lectures, interviews and social networks (see e.g. Ref. [67]). Generosity is also shown by the dedication of the hero to the art of building and to improving people's lives as exemplified by Toni Rüttimann, ${ }^{6-70}$ also known as "Toni el suizo" ("Toni the Swiss"). Rüttimann does not have any diploma in engineering but, shocked by the effects of an earthquake that hit Ecuador in 1987, built a first bridge with the help of a Dutch hydraulic engineer. Since then, he and his team have built over 800 bridges in Southeast Asia and Latin America with the help of the communities served by the bridges, dedicated individuals, private companies, friends and local governments. ${ }^{69} \mathrm{He}$ does not get any salary since he says that he was born to be a bridge builder, but his bridge building approach has significantly improved the quality of life of more than $2,200,000$ people in rural areas. ${ }^{68}$

Finally, perhaps the most important feature of heroes is their passion and love for what they do, which provide an infinite source of energy to overcome all the obstacles of the journey. In Freyssinet's words:

Believe me, young people, if you have a desire to rise above yourselves, your surest way of succeeding will be to love your profession above everything and to give yourself totally to it. This kind of love will give you the strength to surmount fatigue, lassitude and temptations of vanity, cupidity and even fear. ${ }^{33}$

Manterola made a similar comment when he was requested to give advice for young engineers: "You must really love what you want to do. There is no other way out ... It is the only important thing". 58

\section{The Heroes, Diversity and the Education of the Engineer}

Diversity in the engineering profession starts with diversity in the education, and it is not just a matter of ethics because diversity strengthens the profession. Diverse design teams are more effective by bringing synergy through diverse cultural backgrounds, points of views, skill sets and approaches. For underrepresented groups such as women and minorities, Act 1 (departure-call to adventure) is simply entering the Special World where no one looks like them. They must possess courage and confidence to believe that they belong. In this Special World, the monomythical "protective figure" mentors, as well as activism and systems of social, psychological and mutual support (see e.g. Ref. [71]), can make an important positive impact. Upon their "return," Act 3, they inspire others so that eventually-ideally-diversity is no longer a challenge. Examples of such heroes have been shown in the paper and their strength very often comes from their social feats: the courage they had to start and carry out their engineering journey and how they inspired others to start and develop their own, and/or how they changed the lives of many with their engineering work.

The parallels of the structural engineer to the monomythical hero can also be made to education and the educator. The educator should inspire students to become structural engineering heroes and use the academic experience as an instrument for training 
(through the curriculum) and a place to practise their skills (through design projects). Much of the structural engineer's education today is devoted to knowledge of regulation and codes as well as acquiring skills in powerful software that perform both analysis and design. This approach to education keeps instructors and students in their "comfort zone" and will not bring the engineer to the Special World of Act 2 where creativity and courage are practised. Inspiring and preparing a student to enter the Special World includes education in classical theoretical courses, as well classes in the history of our profession (provides inspiration), and an education in the humanities for reasons discussed in the Section "Characteristics of a Hero". This multi-dimensional study of structural design prepares the student for the Special World, where new knowledge is gained and later disseminated. It has been demonstrated, via past or existing designs (see e.g. Ref. [16]), that the greatest designs are disciplined by staying inside of the boundaries of efficiency and economy (the rigorous aspect of engineering) but within the boundaries of discipline there is room to play and integrate the design with culture and elegance (the humanistic and artistic aspect of engineering). The instructional wizard trains the students for the Special World through coursework and through opportunities to practise their training via special design projects. The student in Act 3 then returns to the Ordinary World with the knowledge of an ordinary engineer, and the creativity and courage of an engineering hero who goes on to inspire and train others.

\section{Conclusions}

There is a need (and advantages) to presenting civil engineers as heroes of our society. Using parallels to the monomythical hero, and examples of engineers, the authors have presented the journey and characteristics of the structural engineering hero. The journey, which has many paths, begins with Act 1, Departure, leaving the comfort world of ordinary design into a place where new forms, new materials, and/or scale for projects are needed. For underrepresented groups of people, the heroic journey could be simply becoming an engineer and developing a career in conditions of equity and equality. As the structural engineering heroes enter Act 2, Initiation, into the Special World, they may face trials of nature and criticism, and face constraints of economy time, and knowledge. While in the Special World, they are sometimes aided by colleagues and resources of knowledge. In Act 3, Return, the structural engineering heroes return to the Ordinary World wiser, disseminate their knowledge, and inspire others. The characteristics of the structural engineering heroes are defined by four "P"s: they are prepared (e.g. with tools such as effective education), they are planners (e.g. with drawings/ maps), they have (super) powers (e.g. creativity, courage), and they are persona grata (e.g. generous and passionate). The education of the structural engineer should train and inspire future engineers using the lessons learned from heroes and their diversity, since the profession has benefited from diverse cultural backgrounds, points of views, skill sets and approaches. By doing so, what seems exceptional today can become commonplace in the future.

\section{Disclosure Statement}

No potential conflict of interest was reported by the authors.

\section{ORCID}

Ignacio Paya-Zaforteza (1) http://orcid. org/0000-0002-3995-8772

Maria E. M. Garlock (1) http://orcid. org/0000-0002-6465-9504

\section{References}

[1] Lorenz W. History of construction: an estimable resource in the actual crisis of civil engineering? Proceedings of the first international congress on construction history, Madrid, 2003 Jan 20-24.

[2] Arciszewski T, Harrison C. Successful civil engineering education. J Profl Issues Eng Educ Pract. 2010; 136(1): 1-8.

[3] Garlock M. The art of structural engineering: bridges. MOOC on edX platform, 2018.

[4] Garlock M. The art of structural engineering: vaults. MOOC on edX platform, 2019.

[5] Capa J.V. Personal communication via email to M.E.M. Garlock, 2019.

[6] Ahmend O. Personal communication via email to M.E.M. Garlock, 2020.

[7] International Association for Bridge and Structural Engineering. Proceedings of the
IABSE conference 2017: creativity and collaboration, Bath, 2017 Apr 19-20.

[8] Bergsagel D, Conneely S, Hannigan L, Isaac $\mathrm{P}$, Kennedy S, Koeck A. Inspiring the next generation. IABSE Conference, Bath, 2017: Creativity and Collaboration - Report: 262-265.

[9] Paya-Zaforteza I. Promoting a new generation of people passionate about engineering through a spaghetti bridge building competition. IABSE conference, Bath, 2017: Creativity and Collaboration - Report: 279-285.

[10] [cited 2020 Oct 13]. Available from https:// www.ice.org.uk/events/exhibitions/ice-invisiblesuperheroes-exhibition.

[11] Campbell J. The hero with a thousand faces. New York: Bollingen Foundation, 1949.

[12] Becker E, Burns K. Empire of dreams: the story of the 'star wars' trilogy. Documentary, 2004.

[13] Blasco LF. El viaje del héroe en la narrativa de videojuegos (The hero's journey in videogames' narrative). Quaderns de cine. 2017; 12: 27-33. In Spanish.

[14] Cruz J, Kellam N. Beginning an engineer's journey: a narrative examination of how, when, and why students choose the engineering major. J Eng Edu. 2018; 107(4): 556-582.

[15] Pascual Soler N. Authentic chef-heroes. Food and Masculinity in Contemporary Autobiographies. 2018; 29: 57. doi:10.1007/9783-319-70923-9_2.

[16] Billington DP. The tower and the bridge. The new art of structural engineering. New York: Basic Books, 1983.

[17] istructe.org [Internet]. London: The Institution of Structural Engineers; [cited 2020 Oct 13]. Available from https://www.istructe. org/structuralawards/judges.

[18] iabse.org [Internet]. Zurich: IABSE; [cited 2020 Oct 13]. Available from https://iabse.org/ Bulletin/Press-Releases/OSTRA2020.

[19] asce.org [Internet]. Reston, VA: ASCE; [cited 2020 Oct 13]. Available from https:// www.asce.org/landmarks/.

[20] Lozano-Galant JA, Paya-Zaforteza I. Structural analysis of Eduardo Torroja's Frontón de recoletos' roof. Eng Struct. 2011; 33: 843-854. doi:10.1016/j.engstruct.2010.12.006.

[21] Nervi PL. Aesthetics and technology in building. The Charles Norton Eliot lectures. Cambridge, MA: Harvard University Press, 1965.

[22] Candela F. "La obra de Pier Luigi Nervi" (trans. "The Work of Pier Luigi Nervi"), essay read in El Instituto Nacional de Bellas Artes, Mexico, 1964. Obtained from F. Candela, "En defensa del formalismo y otros escritos" Arquitectos contemporáneos, Xarait Ediciones, Bilbao, 1985. In Spanish.

[23] Allison MG. The Horizon. Section in the magazine "the crisis", 1922 Dec, 75.

[24] Binder D. Big talk at Munich is the big cost of big roof. The New York Times, 1972 Sept 3.

[25] Tomlow J. Designing and constructing the Olympic roof (Munich 1972). Int J Space Struct. 2016; 31(1): 62-73. doi:10.1177/ 0266351116642078. 
[26] Fernádez Ordóñez JA. Eugène Freysinet. Barcelona: 2C Ediciones, 1978.

[27] Billington D. History and esthetics in suspension bridges. J Struct Div. 1977; 103(8): $1655-1672$

[28] Pister KS, Scordelis AC, Wilson EL, Lin TY. In memorial tributes vol. 13: 128-132. The National Academies Press, 2010.

[29] Lin TY. Interaction between architects and engineers. Obra Pública. 1987; 7-8: 99-115.

[30] Billington DP. The art of structural design. A Swiss legacy. Princeton, NJ: Princeton University Art Museum, 2003.

[31] Bonnat L. et al. Les artistes contre la Tour Eiffel. Le Temps, 1887 Feb 14.

[32] Bell GR, Rosowsky DV. On the importance of mentorship and great mentors. Struct Safe. 2021; 91, doi:10.1016/j.strusafe.2021.102076.

[33] Freyssinet E. Eugène Freyssinet by himself. Travaux special issue "a half-century of French prestressing technology” 1966: 3-18.

[34] Steinman DB, Watson SR. Bridges and their builders. New York: Dover Publications, 1957.

[35] Haines CMC. International women in science: a biographical dictionary to 1950. Santa Barbara, CA: ABC-CLIO, 2001.

[36] [cited 2020 Feb 26]. Available from https:// www.ice.org.uk/news-and-insight/latest-icenews/aecom-engineer-most-influential-ft-list.

[37] Lucas S. Meet dot Buchanan. ICE's first lady. New Civil Engineer, 1978 Jul 6: 15-16.

[38] Torroja E. The structures of Eduardo Torroja: an autobiography of engineering accomplishment. Dodge Corporation, 1958.

[39] Oliver M, Buitrago M, Paya-Zaforteza I, Adam JM. Eduardo Torroja's CASA factory roof: an unbuilt structural art masterpiece. Eng Struct. 2016; 128: 82-95. doi:10.1016/j.engstruct. 2016.09.028

[40] Le Corbusier. When the Cathedrals were White. New York: Reynal and Hitchcock, 1947.

[41] Freyssinet E. Souvenirs. Cent ans de béton armé. Paris: Science \& Industrie (supplément à la revue Travaux, $\mathrm{N}^{\circ} 194$ bis, 51-61, 1949.

[42] Bang A. Building bridges and connecting communities. TED archive. Available from https://www.youtube.com/watch? $\mathrm{v}=6 \mathrm{Sr} 0 \mathrm{qQ}$ IK $2 \mathrm{~g} 4$.

[43] Thomas E The global engineers: building a safe and equitable world together. Cham: Springer; 2020. Chapter 7, Avery Bang; p. 63-68.
[44] Cambridge Dictionary. Cambridge University Press. [cited 2020 Dec 28]. Available from https://dictionary.cambridge.org/.

[45] Torroja E. Razón y ser de los tipos estructurales, Instituto de la Construcción y del Cemento, Madrid, 1957. English version: Philosophy of structures. University of California Press, Berkeley and Los Angeles, 1958.

[46] Fernández Troyano L. Ideas y experiencias de un ingeniero de puentes (Ideas and experiences of a bridge engineer). Cuadernos de diseño en la Obra Pública. 2019; 10: 4-37. In Spanish.

[47] Billington DP. Robert Maillarts bridges: the art of engineering. Princeton: Princeton University Press, 1979.

[48] Laprade A. Adieu à Eugéne Freyssinet. Bul.letin of the Société des Architectes Diplômes par le Gouvernement 1962 June.

[49] Petroski H. Success through failure. The paradox of design. Princeton, NJ: Princeton University Press. 2006.

[50] Holgate A. The art of structural engineering. The work of Jörg Schlaich and his team. Stuttgart: Edition Axel Menges, 1997.

[51] Guisasola M. Design philosophy based on the span's internal forces. Struct. Eng. Int. 2021. doi:10.1080/10168664.2020.1871308

[52] Revilla R, Cambronero F, Cembrero P, Olazábal P. Bridge design a creative process. Struct. Eng. Int. 2021. doi:10.1080/10168664. 2021.1885322

[53] Han Z. Aesthetics innovation and practice of urban bridge design. Struct Eng Int. doi:10 1080/10168664.2020.1848368.

[54] Zaforteza IP, Janberg N. Editorial. Proc Inst Civil Eng - Eng Hist Herit. 2018; 171(3): 91. doi:10.1680/jenhh.2018.171.3.91.

[55] Freyssinet E. Les hangars a dirigeables de l'aeroport d'Orly. Génie civil, 1923.

[56] Kawaguchi M. The design of structures. From hard to soft. In Seven structural engineers. the Felix Candela lectures. New York: The Museum of Modern Art.

[57] Manterola J. Lecture given in occasion of the presentation of the issue 10 of the journal "Cuadernos de diseño en la obra pública". Available from https://www.youtube.com/ watch? $\mathrm{v}=\mathrm{PqYhuYSwHNU} \& \mathrm{t}=5729 \mathrm{~s}$.

[58] Manterola J. Interviewed for the course "The art of Spanish bridge design". Available from https://www.youtube.com/watch? $\mathrm{v}=\mathrm{Y}$ iBtW4mVs\&feature=youtu.be
[59] Sobrino J. Interviewed for the course "The art of Spanish bridge design". Available from https://www.youtube.com/watch?v=NFKPI_8CUw\&feature $=$ youtu.be

[60] Schlaich J. On the conceptual design of structures. An introduction. Proceedings of the international association for shell and spatial symposium conceptual design of structures, Stuttgart, 1996.

[61] Schlaich J, Keil A, Fackler T, Weißbach M, Goldack A. German railway bridges - new paths of conceptual design. IABSE Symp Rep. 2010; 97 (31): $1-8$.

[62] Barksdale-Hall R. The testimony of William Hunter Dammond: the first African American graduate of the University of Pittsburgh. $J$ Pan African Stud. 2007; 1(8): 120-126.

[63] Du Bois WEB. Letter from W.E.B. Du Bois to W.H. Dammond, January 11, 1923. W.E.B. Du Bois Papers (MS 312). Special Collections and University Archives, University of Massachusetts Amherst Libraries.

[64] Dammond WH. Letter from W.H Dammond to W.E.B. Du Bois, February 19, 1923. W.E.B. Du Bois Papers (MS 312). Special Collections and University Archives, University of Massachusetts Amherst Libraries.

[65] Du Bois WEB. Letter from W. E. B. Du Bois to William H. Dammond, April 12, 1923. W. E. B. Du Bois Papers (MS 312). Special Collections and University Archives, University of Massachusetts Amherst Libraries.

[66] Dammond WH. Letter from W.H Dammond to W.E.B. Du Bois, September 6 , 1923. W.E.B. Du Bois Papers (MS 312). Special Collections and University Archives, University of Massachusetts Amherst Libraries.

[67] Agrawal R. Built. The hidden stories behind our structures. New York: Bloomsbury Publishing, 2018.

[68] Alatalo E. Case study of two Toni Rüttimann bridges in Myanmar. Struct Eng Int. 2020; 30(1): 18-22. doi:10.1080/10168664.2019.1628620.

[69] Alatalo E. Toni Rüttimann and his bridge building approach. Struct Eng Int. 2020; 30(1): 8-11. doi:10.1080/10168664.2019.1628619.

[70] Schneider J. Toni-style suspension bridge construction. Struct Eng Int. 2020; 30(1): 12-17. doi:10.1080/10168664.2019.1615856.

[71] Bix AS. From "engineeresses" to "girl engineers" to "good engineers": a history of women's U.S. engineering education. NWSA $J$. 2004; 16(1): 27-49. 